\title{
Memória
}




\section{Contra qualquer ordem internacional}

\section{SEVERO GOMES}

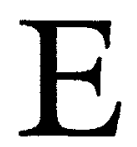

m primeiro lugar quero lembrar que o Relatório da Comissão Sul é bastante realista. Ele deixa evidente que os países do Sul são desprovidos de soberania funcional. Mostra com muita clareza que todos os processos de tomada de decisóes sáo controlados pelos países desenvolvidos e pelas instituiçóes internacionais que eles dominam. Fala do aumento de poder do Norte e do destino do Sul ser cada vez mais determinado pelas percepçóes e políticas dos governos daquela região. Esta é uma realidade bastante clara no referido Relatório da Comissão Sul. Ele também inclui proposiçóes éticas que sempre delinearam a vontade dos povos de buscar caminhos melhores. A guerra do Vietnã acabou por razōes éticas e não porque os americanos tivessem acabado suas bombas. Era impossível sustentar aquele tipo de chacina e foi - vamos dizer assim - a cidadania americana que acabou com a guerra do Vietnã.

Tenho de falar sobre as relaçōes Sul-Sul: sempre que quisermos pensar nisso deveremos nos lembrar que essas relaçóes Sul-Sul estão ocorrendo dentro do quadro de uma ordem internacional. Essa ordem internacional só existe porque há um poder que a sustenta e, portanto, essa ordem vai trabalhar para satisfazer os interesses desse poder, quer dizer, nós vamos ficar cada vez mais pobres. Segundo o Prof. Amilcar Herrera, no ano 2000 a população do Terceiro Mundo será de $90 \%$ e não $75 \%$ da população total, como é hoje. A tendência é uma degradaçáo nesse sentido.

Essa ordem funciona porque tem um poder. Como está hoje esse poder? Tentou-se mudar a ordem econômica internacional, a partir de

Este texto transcreve a opinião (não revista) de Severo Gomes no debate sobre o Relatório da Comissão Sul, realizado em 21 de outubro de 1992, no IEA. O evento foi aberto pelo economista Celso Furtado, um dos integrantes brasileiros da Comissão, instituída em 1987, depois de anos de discussão entre dirigentes políticos e intelectuais dos países do Sul. A proposta inicial foi do primeiro ministro da Malásia, Mahatir Mohamad, e liderada pelo ex-presidente da Tanzânia, Julius K. Nyerere. As conclusōes da Comissão foram publicadas em forma de livro com o título O Desafio do Sul (Portugal, Ediçốes Afrontamento, 1990). O livro está a venda nas livrarias da Editora da USP (Edusp). 
1974, com uma decisão das Nações Unidas. De lá pra cá, aquela aspiração de uma nova ordem econômica não só deixou de ocorrer como a situação piorou para os países do Terceiro Mundo. Então, o diálogo Sul-Sul deve ser pensado dentro de um quadro da ordem econômica internacional. Ela pode mudar para o bem ou para o mal, mas mudará. Existe o projeto Bush da Nova Ordem Mundial, há o projeto da Pax Americana. Esses projetos (Bush ou Pax Americana), porém, sáo para manter o mesmo tipo de domínio e o mesmo tipo de exploração. Eles não querem fazer qualquer sacrifício que ponha em risco o seu bem-estar, mas melhorar as condiçóes de vida nos países mais ricos.

Torna-se difícil a manutenção da atual ordem e da hegemonia norte-americana, e é nisso que poder-se-ia trabalhar para se ter alguma esperança no Sul Fora disso, o que teremos será o agravamento da situação do Sul em relação à do Norte. Quer dizer, há alguma esperança de que surjam conflitos de interesses dentro do Norte ou, entáo, que eles cometam erros extremamente grosseiros.

Nos EUA, hoje, já existe uma marcha no sentido daquilo que sempre inspirou no passado a diplomacia americana o seu isolamento, do qual raras vezes saiu, até a Segunda Guerra Mundial.

Alguma mudança poderá ocorrer. A tendência hoje, poder-se-ia dizer, desde há alguns anos, é a busca do isolacionismo americano. Mesmo as últimas leis aprovadas em 1988-89 no Congresso Americano já é legislação que impede ou dificulta a entrada de capitais estrangeiros na atividade produtiva e na compra de

\section{Sepero Gomes}

Em outubro do ano passado uma tragédia comoveu a opinião pública brasileira. Entre Angra dos Reis e São Paulo, caiu no mar o helicóptero em que viajavam o deputado Ulysses Guimaráes, o ex-senador Severo Gomes, D. Mora Guimarães e D. Maria Henriqueta Gomes, além do piloto Jorge Bandeira. A tragédia se prolongou durante várias semanas, pois foi muito difícil o resgate dos mortos, sendo em vão os trabalhos para a localizaçáo do corpo de Ulysses Guimarães.

Pelo papel que desempenhou na vida política do Brasil, desde os anos 40, o desaparecimento de Ulysses Guimaräes chocou a consicência nacional. Nos diversos postos de relevância que ocupou na administração pública, mas especialmente pela sua profícua atividade como parlamentar, Ulysses Guimaráes afirmou-se como ụm líder da causa democrática, como uma figura de notável sensibilidade com relação aos grandes problemas nacionais.

Severo Gomes, a partir dos bancos acadêmicos, igualmente teve uma trajetória invulgar. Como empresário, sobressaiu-se 
pelo fato de buscar comprometer os meios industriais com teses progressistas e de cunho social, porque era um estudioso da História brasileira, homem de seu tempo, conhecedor das questóes controversas da realidade do País e do mundo.

Esses traços básicos levaram Severo Gomes, no exercício de diversas funçóes na República e em São Paulo, inclusive no Senado, a se destacar pelo destemor na manifestaçáo de seu espírito público e pela defesa de suas convicçóes.

Nos últimos anos, Severo Gomes atuou no Instituto de Estudos Avançados da USP como professor visitante, conferencista e debatedor, sempre dando contribuiçóes marcadas pela erudição de sua formação cultural e diuturna preocupação em encontrar caminhos para o desenvolvimento do País e fundamentação de nossa identidade nacional.

* Marco Antonio Coclboé editor execurivo da revista Estudos Avanfados. bens imóveis rurais ou urbanos naquele país.

Tenho aqui um texto, que me parece bastante esclarecedor neste debate, com relação à política americana. Até que ponto devemos analisá-la e de que modo essa política poderá, amanhá, ser confrontada com as aspiraçóes japonesas ou as do Mercado Comum Europeu? É texto de um economista do Economic Strategic Institute, publicado no The Atlantic Month, e diz: "Os americanos devem começar pensando a sua política externa em termos de evitar problemas, reduzir vulnerabilidades e custos, maximizando opçóes, ganhando tempo e objetivos que podem ser não tão inspiradores, mas adequados para um país forte, saudável $\mathrm{e}$ geograficamente isolado". Isolacionismo mais claro figura no capítulo sobre Terceiro Mundo. "Washington sozinha é o juiz, o júri e a corte de apelação. Países que desobedeçam serão punidos talvez pela forma de bombardeiro aéreo ou naval, ou por embargo econômico. De qualquer modo, países que desobedeçam serão deixados de lado."

Há um pensamento que se baseia em realidade antiga da vocação isolacionista americana e convicçáo de que poderão agir no mundo como agiram na Guerra do Golfo; com pressão violenta $\mathrm{e}$ alcançando seus objetivos. Quer dizer, será impraticável pensar num diálogo Sul-Sul sem imaginar como essas grandes figuras do Norte irão jogar, de modo que nós temos de lutar contra uma ordem internacional. $\mathrm{O}$ Brasil só teve grandes oportunidades entre as duas grandes guerras, porque não havia essa ordem internacional. Não havia ordem porque 
não havia poder que the desse sustentação. Tivemos, em 1922, não só a Semana de Arte Moderna, mas o início da indústria metalúrgica em Sáo Paulo, a criação do Instituto Nacional de Tecnologia, a fundaçáo do Partido Comunista, o levante do Forte de Copacabana, todos acontecimentos simultâneos, mas que guardam entre si nexo extremamente importante. Agora, como deveremos trabalhar para impedir uma ordem internacional? Porque esta é fatal para todos nós.

Aí tenho discordância com o Prof. Goldemberg, quando ele critica o Relatório; porque este dá ênfase ao desenvolvimento tecnológico. Ora, o que nós sabemos é que o desenvolvimento tecnológico, hoje, significa poder, pura e simplesmente. Nós náo vamos ter acesso ao conhecimento tecnológico que nos dê poder. Quero lembrar até um episódio curioso e contraditório. Na única reuniāo do Conselho da República, o Presidente Collor procurou nos mostrar um dos aspectos negativos do mundo em que estamos vivendo. Indicou ele que depois da Guerra do Golfo é impraticável a transferência de tecnologia, é impossível comprar tecnologia. Ele disse: "estão fechados". Curiosamente, isso é contraditório com nossas açóes internas no Brasil. Essas açóes internas visam a demolir os esforços nacionais para o desenvolvimento tecnológico. Essas açóes nacionais visam a demolir o que se avançou na informática. Quiseram até fechar a Embraer, e só não conseguiram porque os aviadores se sublevaram; caso contrário, teriam-na fechado. $O$ discurso permanente de submeter o país à fiscalização da Agência Internacional de Energia Atômica significa recuo, rendição naquilo que é importante ser feito: $O$ avanço tecnológico. Isso é uma das coisas importantes do Relatório.

A nossa possibilidade é de desenvolver o diálogo Sul-Sul, e o mérito desse Relatório é apontar um caminho. Todo novo e bom caminho tem que ter proposta política. Agora, este caminho passa pela consciência de que qualquer ordem internacional vai transformar o diálogo Sul-Sul em conversas na senzala.

O nosso trabalho político é lutar contra uma ordem internacional e esperar até que eles cometam erros. Aquilo que aparece no horizonte será o conflito de interesses de países do Norte com Japão, Ásia e Mercado Comum Europeu. Os americanos, hoje, embora sempre tenham se considerado como campeóes da liberdade econômica, estáo cada vez mais restringindo-a, porque a liberdade é boa para o forte, ela é a geradora de desigualdade. A liberdade só pode existir quando existe lei que a regule, é aquela que pode existir dentro dos países, dentro das naçóes. A lei impede que o forte mate o fraco. Essa lei não existe fora dos países. No mundo internacional a liberdade é sempre a geradora da desigual- 
dade porque quem tem força pode usá-la do jeito que bem entender. Então, esse país, que foi o campeáo da liberdade, agora começa a restringir a liberdade econômica, porque sabe que outras forças poderão influir e levá-lo a situaçáo econômica mais difícil, sendo conhecida a fragilidade da economia norte-americana da atualidade.

Entáo, para o diálogo Sul-Sul, existe apenas uma oportunidade. Falou-se aqui sobre a falta no Relatório de proposta concreta do que fazer. Acho que é lutar contra a construçáo de qualquer ordem internacional $e$, por esse caminho, já estaremos unidos para conversar. 